\section{THE "SUMMER TIME" BILL.}

" $\mathrm{HE}$ main provisions of the "Summer Time" Bill, which was introduced in the House of Commons on May 9 by the Home Secretary, Mr. Herbert Samuel, and was read a second time in the House of Lords on May 16, are as follows :-

(I) During a prescribed period the local time in Great Britain is to be one hour in advance of Greenwich mean time.

(2) The prescribed period this year is from two o'clock in the morning Greenwich mean time on Sunday, the twenty-first day of May, until two o'clock in the morning Greenwich mean time on Sunday, the first day of October, and during the continuance of the present war the Act can be declared by Order in Council to be in force for any prescribed period.

(3) During the prescribed period any expression of time in any Act of Parliament, Order in Council, order, regulation, rule, or by-law, or in any deed, time-table, notice, advertisement, or other document, is to mean "Summer Time."

(4) The Act is to apply to Ireland as to Great Britain, with the substitution, however, of references to Dublin mean time for references to Greenwich mean time.

(5) Greenwich mean time is to be maintained as hitherto, for purposes of astronomy or navigation.

No particular time is prescribed for meteorologists, who are left to decide for themselves whether to record their observations at the same hour G.M.T. throughout the year, or to adopt the Summer Time for five months and G.M.T. for the remainder. A like difficulty arises with self-registering meteorological instruments, which are used to record continuously day and night. Either the instruments are to be an hour wrong in the summer, or meteorologists are to use a time-system different from that of the general public. For example, the five thousand voluntary observers connected with the British Rainfall Organisation record their readings at 9 a.m., which is to be ro a.m. Summer Time. Dr. H. R. Mill, director of the Organisation, has had to announce to his observers that the readings should be taken, if possible, at 9 a.m. G.M.T., as hitherto, or a note should be made on each page of the observation book if the readings are taken at 9 a.m. Summer Time. Anyone who is concerned with the preservation of records for long series of years must contemplate with blank dismay the dual system about to be introduced.

Lighting-up times, as was stated in last week's Nature, depend upon local times of sunset, and are therefore based upon Greenwich mean time, with differences for latitude and longitude. The Law Journal points out that since sunrise and sunset always mean in law the exact moment at which the sun rises or sets at any particular place, the obligation to light up vehicles an hour after sunset-an interval which is reduced to half an hour during the war-is not affected by the Summer Time Bill. The law will thus maintain local time for many of the statutes in which time is mentioned, and this, for nearly all places in Great Britain and Ireland, will be later than Greenwich time, not an hour earlier, as the Summer Time Bill prescribes. As the tides, sunrise and sunset, lunar phases, and like occurrences belong to navigation and astronomy, they will continue to be tabulated in advance in Greenwich time; but all public clocks are to show mid-European time.

The economic and social advantages claimed for this introduction of confusion into an orderly system of time-reckoning remain to be seen; but whatever they are there can be no question that the scheme of a fluctuating time-standard has no natural basis. It is the duty of a scientific journal to point out the objections to the scheme, even though it stands alone, and, in the opinion of the public, may represent what is contemptuously termed scientific theory as something apart from the practical needs of life. The diffculties are not appreciated by our legislators, and few writers in the public Press have shown any intelligent understanding of them, while scientific interests have been completely disregarded. The only satisfaction to be derived from this childish method of promoting the increased use of daylight is that the measure is limited to the period of the war.

\section{PURIFICATION OF COAL-GAS.}

PROF. FRANK CLOWES read a paper before the Society of Chemical Industry on May I dealing with the past and present of the sulphur impurity in coal-gas. He recalled that the higher temperature carbonisation arising from the displacement of iron by fireclay retorts had resulted in an increased amount of sulphur coming into the gas, not only in the form of hydrogen sulphide, but more noticeably as sulphur compounds of an organic nature. Purification by iron oxide is sufficient to remove sulphuretted hydrogen, but the removal of these organic compounds is much more difficult. "Sulphided lime," prepared by passing coal-gas containing hydrogen sulphide, but free from carbon dioxide, over freshly slaked lime, was in common use for the purpose, but its action was so uncertain that a Board of Trade Committee which inquired into the subject came to the conclusion that any statutory requirement that the sulphur impurities should be removed to such an extent as to demand the use of lime ought to be discontinued. The detrimental physiological effect and very slight, or non-existent, disinfectant value of the sulphurous products of combustion of coal-gas were, however, plainly indicated by Dr. Haldane, and experimental results were also brought forward which proved that these sulphurous products caused leather to rot and ultimately to crumble, and that some fabrics were similarly affected.

Dr. C. Carpenter and his collaborators have advanced matters by working out on the large scale a practical method of removing carbon bisulphide by passing the gas at a temperature of about $45^{\circ} \mathrm{C}^{1}$ (the author gives the temperature $450^{\circ} \mathrm{F}$., presumably a misprint) over fireclay surfaces impregnated with reduced nickel. The hydrogen sulphide formed is removed by subsequent exposure of the coal-gas to iron oxide, and the carbon deposited on the fireclay-nickel surface is burned off; the sulphur of the coal-gas is so reduced to about 8 grains per Ioo cubic feet.

A similar process is in the hands of an investigator in France, and it appears that the immediate possibility of distributing a much purer gas supply is presented to the gas industry.

\section{PREHISTORIC ART.}

A MELANCHOLY interest attaches to a paper A entitled "Nouvelles découvertes à Laugerie Basse: Rabots, os utilisés, œuvres d'art," by Capt. Bourlon, published in the last issue of L'Anthropologie (vol. xvii., Nos. I- 2, for January-April), because the gallant officer was killed at the opening of the war. The paper has now been edited by M. 1'Abbé Breuil. These new discoveries in this famous cave are of remarkable interest, including a fine collection of flint implements, among which the rabots, or scrapers, are of exceptional interest. We have also fine examples of work in bone, including many heads of animals engraved on this material. The engravings on stone, besides those of the normal type, display some curious variants. Of these the most remarkable are a splen-

\footnotetext{
1 Trans. Inst. Gas Eng., rgr 4, p. $2 \mathrm{r}_{3}$
}

No. 2429, VOL. 97] 
did picture of a red bear, stags, bison, and a figure of a bird with a long, slightly curved beak, with a protuberance on the throat, which may make it possible to identify the species.

This type of prehistoric art is also illustrated in a novel way in a paper in the same issue of $L^{\prime} A n t h r o-$ pologie by M. E. F. Gautier, entitled "Nouvelles Stations de Gravures rupestres Nord-Africaines," which describes a series of rock sculpturings at a place to the north of Figuig, on the Algerian-Moroccan frontier. These include elephants, lions, an animal possibly a giraffe, and ostriches. The author remarks that eminent geologists, on the analogy of the prehistoric drawings in the French caves, are disposed to assign the North African specimens to the Quaternian age. But he warns us that the collection of examples was made in the course of a rapid tour, and that it is still far from complete. Much further exploration is required before any definite conclusiun regarding this type of prehistoric art and the ethnology of the artists can be formulated.

\section{SCIENCE AND CLASSICS IN MODERN EDUCATION.1}

$T \mathrm{HE}$ resolution $\mathrm{I}$ have the honour to move seems to need but few words to commend it to a meeting of scientific men. But we have to bear in mind that it is not scientific men that have to be convinced, and it becomes necessary therefore to state clearly what it is that we desire, and why we desire it.

I propose to begin, however, by stating what it is that we do not desire, my reasons for so doing being that our aims have been grossly misrepresented in the past, as they will no doubt continue to be misrepresented in the future. Thus, in expressing the opinion that science ought to oust the study of Greek and Latin from the prominent position which these subjects hold in the educational course of our schools, we have been accused of wishing to kill all learning but our own. The accusation is baseless. We have never expressed any such desire. No one of us would be so foolish as to wish that the classics should not continue to be a serious branch of study. We do not contest that an intimate knowledge of Greek and Latin may help towards the attainment of literary and oratorical style, or that it may even add to the amenities of conversational intercourse. We admire - some of us from a long distance-the favoured few who are possessed of those advantages. But it is the many we have to consider in the matter of general education, and we ask ourselves-looking over the circle of our acquaintances at those who have had the inestimable privilege of having Greek and Latin swished into them from their earliest years-whether in the great majority there is any sign that there was ever much penetration beyond the skin, and whether the educational benefits which the-for the most part longforgotten-acquisition of these languages has bestowed are really worth the enormous amount of time and trouble expended upon them. This is, of course, an entirely different question from what I may perhaps be permitted even by our opponents to call the scientific study of classical languages and literature, which is on an altogether different footing, and cannot be promoted by forcing Greek and Latin on every schoolboy, whether he has aptitude for it or not, to the exclusion of subjects the knowledge of which would at least be of some benefit to him in after life.

We must all admit that there is not time for any adequate study of both the classics and the natural

1 Remarks made by Sir Edward Schäfer, F.R.S., in proposing the first resolution at the meeting $n$ the Neglect of Science held at Burlington House on May 3 (see Naturf, May ix, p. 23o). sciences in the general educational curriculum; surely, therefore, it is scarcely titing to omit subjects which in any conceivable circumstance of life may prove of some value in order to retain those which can only be valuable in professions which demand a certain standard of literary attainment. But I am not prepared to concede that knowledge of the classics is necessary for the production of the best English. I refer to this point particularly because the claim has been recently made by one of the champions of the present system of education that without such knowledge we are unable adequately to express our ideas in our own language. The absurdity of this contention is obvious at a time when we are commemorating the tercentenary of the author whose immortal works were written under all the disadvantages of the possession of "small Latin and less Greek." Perhaps it is unfair to bring in evidence so transcendant a genius as Shakespeare; he, one feels, even with a complete classical education, would still have succeeded in bewitching the world with his wonderful imaginings and in inspiring his characters with the attributes and sentiments which his puny fellow-mortals have marvelled at for three hundred years, and will doubtless continue to admire as long as our world continues. Nevertheless, if Shakespeare had gone through a course of Eton and Oxford the language those sentiments are clothed in would certainly have been different, and I imagine that not even the most proclassical of our opponents but is thankful that he escaped.

I am content, however, to leave Shakespeare on his pinnacle-unattained and unattainable-and to recall the name of one John Bunyan. Has anyone amongst the polished eighteenth-century essayists written in a clearer style than this Bedfordshire tinker's son, whose literary studies were mainly confined to the Bible? Or, to take an instance from our own times, was there ever a finer political speaker than John Bright, "the great tribune," whose utterances, couched in simple, vigorous English, were wont to pass straight from his own heart to that of his audience? And is there not another writer and speaker of whom we are many of us proud to have been the disciples, and whose spirit we may well imagine to be with us this afternoon, who, without the advantage of a classical upbringing, was pre-eminent amongst nineteenthcentury authors for his faultless diction and for the direct and terse enunciation of his ideas; needless to say, I refer to Thomas Henry Huxley.

We have further been accused of desiring, in our enthusiasm for science, to oust such subjects as modern history, and geography, and the study of the English language and literature from the educational curriculum. No accusation can be more unfair. We recognise that these subjects must for us form a fundamental part of all education. They have been ousted from the present scheme because their immediate relation to the classical languages and literature was remote, and the amount of knowledge of Greek and Latin which has been required in competitive examinations has needed all the time at the schoolmaster's disposal. We believe, however, that there will, if the greater part of that time can be recovered, be opportunity afforded for the acquisition of such knowledge of the subjects in question as will help to fit our boys and girls to become worthy citizens of this great island-empire.

But in order that there shall be a reasonable chance of our being able to maintain our place in the world it is above all necessary that we should move with the times. We are a long way from the eighteenth century - when a sound education in classics was recognised as the be-all and end-all of a boy's upbring- 